\title{
Pola Asuh Keluarga dan Pemberian MP ASI Dini dengan Status Gizi Balita di Kelurahan Cipayung Jakarta Timur
}

\author{
Yeny Sulistyowati, Sri Utami, Ade Citra Welasti \\ Universitas Respati Indonesia \\ Email: yeny.sulistyowati@urindo.ac.id
}

\begin{abstract}
ABSTRAK
Latar Belakang: Masalah gizi dipengaruhi oleh banyak faktor yang saling mempengaruhi secara kompleks. Ditingkat rumah tangga, keadaan gizi dipengaruhi oleh kemampuan rumah tangga menyediakan pangan dalam jumlah dan jenis yang cukup serta pola asuh yang dipengaruhi oleh faktor pendidikan, perilaku dan keadaan kesehatan rumah tangga. Salah satu penyebab timbulnya kurang gizi pada anak balita adalah akibat pola asuh anak yang kurang memadai. Kekurangan gizi pada masa Balita dapat menimbulkan gangguan tumbuh kembang secara fisik, mental, sosial dan intelektual yang sifatnya menetap dan terus dibawa sampai anak menjadi dewasa. Pengasuhan, kesehatan dan makanan pada tahun pertama kehidupan sangatlah penting untuk perkembangan anak. Makanan Pendamping ASI (MP ASI) adalah makanan yang diberikan pada bayi usia sebelum 6 bulan, fenomena ini banyak di jumpai di masyarakat. Wilayah Puskesmas Cipayung terdapat sebanyak $74,1 \%$ Balita yang ditimbang dan 0,41\% menderita Gizi Buruk, sejumlah 48 Balita. Tujuan: Penelitian ini bertujuan untuk mengetahui Pola Asuh Keluarga dan Pemberian MP ASI Dini dengan Status Gizi Balita di Kelurahan Cipayung Jakarta Timur serta faktor yang mempengaruhinya. Metode: Penelitian ini menggunakan metode survei analitik dengan pendekatan crossectional. Jumlah sampel penelitian sebanyak 67 responden. Data dikumpulkan dengan wawancara melalui kuesioner dengan diuji terlebih dulu secara terstruktur. Uji statistik menggunakan Chi square. Hasil: Balita di Kelurahan Cipayung Jakarta Timur ada 67 orang terdapat 47 (70.1 \% ) balita gizi normal dan terdapat 20 (29.9 \%) balita gizi tidak normal. Variabel pola asuh dan pemberian MP-ASI berhubungan signifikan dengan status gizi balita. Hasil penelitian ini diharapkan dapat memberikan informasi mengenai status gizi balita dan dapat menurunkan angka kejadian gizi balita di wilayah kerja Puskesmas Cipayung Jakarta Timur, khususnya di Kelurahan Cipayung.
\end{abstract}

Kata Kunci: Pola Asuh, Makanan Pendamping ASI Dini, Status Gizi

\section{ABSTRACT}

Background: Nutritional problems are influenced by many factors that influence each other in a complex manner. At the household level, nutritional status is influenced by the household's ability to provide adequate amounts and types of food and parenting styles which are influenced by education, behavior and household health conditions. One of the causes of malnutrition in children under five is the result of inadequate parenting. Malnutrition in toddlers can cause physical, mental, social and intellectual growth and development disorders that are permanent and continue to be carried over until the child becomes an adult. Parenting, health and nutrition in the first year of life are very important for a child's development. Complementary food for breast milk (MP ASI) is food given to infants aged before 6 months, this phenomenon is often encountered in the community. In the Cipayung Health Center area, there were $74.1 \%$ of toddlers who were weighed and $0.41 \%$ suffered from malnutrition, a total of 48 toddlers. Objective: This study aims to determine Family Parenting Patterns and Early MP ASI with Nutritional Status of Toddlers in Cipayung Village, East Jakarta and the factors that influence them. Methods: This study used an analytical survey method with a cross-sectional approach. The number of research samples as many as 67

http://ejournal.urindo.ac.id/index.php/kesehatan

Article History :

Sumbitted 19 Desember 2021 Accepted 30 Desember 2021, Published 31 Desember 2021 
respondents. Data were collected by interviewing through a questionnaire with a structured first test. Statistical test using Chi square. Results: There were 67 children under five in Cipayung Village, East Jakarta, there were 47 (70.1\%) under-fives with normal nutrition and 20 (29.9\%) under-fives with abnormal nutrition. The variables of parenting and the provision of complementary feeding are significantly related to the nutritional status of toddlers. The results of this study are expected to provide information on the nutritional status of toddlers and can reduce the incidence of under-five nutrition in the work area of the Cipayung Health Center, East Jakarta, especially in Cipayung Village.

\section{Keywords: Parenting Patterns, Early Breastfeeding Complementary Foods, Nutritional Status}

\section{Pendahuluan}

Persoalan gizi dalam pembangunan kependudukan masih menjadi masalah utama dalam tatanan kependudukan dunia. Oleh karena itu, hal ini menjadi salah satu butir penting yang menjadi kesepakatan global dalam Milleneum Development Goals (MDGs). Riset Kesehatan Dasar (2013) mencatat bahwa prevalensi anak dengan gizi kurang di Indonesia pada Tahun 2013 sebanyak 12,1\%, diantaranya balita sangat kurus sebanyak 5,3\% dan kurus sebanyak 6,8\%. Menurut WHO (2010) masalah kesehatan gizi masyarakat sudah dianggap serius bila prevalensi gizi kurang antara 10-14\% dan dianggap kritis bila $\geq 15 \%$. Prevalensi anak balita gizi kurang secara nasional pada tahun 2013 masih 12,1\%, yang artinya masalah gizi kurang di Indonesia masih merupakan masalah kesehatan masyarakat yang serius (Riskesdas, 2013).

Menurut Profil Kesehatan Kecamatan Cipayung, angka kejadian balita gizi buruk paling tinggi ada di Puskesmas Bambu Apus 1 (1,05\%), Puskesmas Cilangkap (0,9\%) dan
Puskesmas Ceger (0,64\%). Wilayah kerja Puskesmas Cipayung terdiri dari 11 Puskesmas Kelurahan yang ada di wilayah Kecamatan Cipayung.

Masalah gizi dipengaruhi oleh banyak faktor yang saling mempengaruhi secara kompleks. Ditingkat rumah tangga, keadaan gizi dipengaruhi oleh kemampuan rumah tangga menyediakan pangan dalam jumlah dan jenis yang cukup serta pola asuh yang dipengaruhi oleh faktor pendidikan, perilaku dan keadaan kesehatan rumah tangga. Salah satu penyebab timbulnya kurang gizi pada anak balita adalah akibat pola asuh anak yang kurang memadai. Pengasuhan kesehatan dan makanan pada tahun pertama kehidupan sangatlah penting untuk perkembangan anak (Soekirman, 2005; Santoso, 2005).

Makanan pendamping ASI (MP ASI) Dini adalah makanan yang diberikan kepada bayi selain ASI. Jenis dan karakter dari makanan tersebut disesuaikan dengan umur bayi. MP ASI Dini merupakan makanan dan minuman yang mengandung gizi yang 
diberikan kepada bayi atau anak untuk memenuhi kebutuhan gizinya yang diberikan sebelum bayi berusia 6 bulan (Rahmawati, 2014). Secara nasional pemberian MP ASI di Indonesia berfluktuasi dan menunjukkan kecenderungan meningkat selama 3 tahun terakhir. Pada tahun 2011 MP ASI Dini sebesar $61,5 \%$ menurun menjadi $36,6 \%$ pada tahun 2012 dan meningkat lagi sebesar 45,7 \% pada tahun 2013 (Depkes RI, 2013). Menurut (SDKI, 2012) penyebab utama kematian pada balita adalah diare yaitu sebesar 25,2\% dan kematian akibat ISPA sebesar 15,5\%. Salah satu faktor risikonya adalah pemberian MP ASI Dini.

Berdasarkan latar belakang yang telah diuraikan, rumusan masalah sebagai berikut : "Apakah Ada Hubungan Pola Asuh Keluarga dan Pemberian MP ASI Dini dengan Status Gizi Balita Gizi di Kelurahan Cipayung Jakarta Timur?".

Tujuan khusus: (a)Mengetahui pola asuh keluarga; (b)Mengetahui pemberian MP ASI Dini; (c)Mengetahui status gizi balita; (d)Mengetahui hubungan pola asuh keluarga dengan status gizi balita; (e)Mengetahui hubungan pola asuh keluarga dengan status gizi balita. Penelitian ini diharapkan mampu memberikan wawasan keilmuan pada mahasiswa bimbingan secara terstruktur dan studi diselesaikan tepat waktu.

\section{Metode}

Jenis penelitian ini adalah penelitian observasi analitik, dengan desain crossectional (Sutanto, 2017). Tempat Penelitian dilakukan di Wilayah Kerja Kelurahan Cipayung. Penelitian dilaksanakan mulai bulan Februari Nopember 2020. Populasi kasus pada penelitian ini adalah balita di wilayah kerja Kelurahan Cipayung Sampel merupakan bagian dari populasi yang dipilih melalui cara tertentu sehingga dianggap dapat mewakili populasinya, digunakan jumlah responden sejumlah 67 Balita. Variabel Penelitian terdiri dari : a. Variabel terikat (dependent variable) dalam penelitian ini adalah balita dengan status gizi. b. Variabel bebas (independent variable) dalam penelitian ini adalah pola asuh keluarga, pemberian MP ASI Dini. Prosedur dalam pengumpulan data penelitian ini memerlukan beberapa tahap diantaranya: (1). Meminta surat pengantar untuk melakuan penelitian setelah proposal disetujui (Pembuatan proposal, perijinan, koordinasi) (2). Tahap Persiapan Wawancara dan observasi (3). Tahap Pelaksanaan: Mengajukan surat permohonan izin, mengajukan surat permohonan izin kepada calon responden yang bersedia berpartisipasi dalam penelitian, Menjelaskan tentang manfaat penelitian, tujuan penelitian, dan kerahasiaan informasi yang akan diperoleh dari responden, Pengisian 
informed concern (4) Editing, Coding, Entry Data, Tabulating (5). Tahap Pengolahan Data Pencatatan data (6). Analisa data dengan Program Komputer (Analisis univariat dan analisis bivariat).

Instrumen Penelitian pada penelitian ini alat pengambilan data yang digunakan berupa panduan checklist observasi dengan mengacu pada landasan teori. Cara pengambilan data melalui observasi yang digunakan dalam bentuk checklist yaitu mengenai pola asuh dan pemberian MP ASI Dini serta pengukuran status gizi. Pengolahan Data dan Analisa. Data yang telah terkumpul dianalisis dengan menggunakan program SPSS. Analisis data meliputi: (1). Analisis Univariat Analisis univariat untuk menggambarkan distribusi frekuensi masing-masing variabel, baik variabel bebas (pola asuh, pemberian MP ASI), variabel terikat (status gizi balita) maupun deskripsi karakteristik responden. (2). Analisis Bivariat menggunakan uji chi square untuk mengetahui hubungan antara variabel bebas dengan variabel terikat. Etika Penelitian akan diajukan kepada Komite Etik Penelitian Kesehatan Universitas Respati Indonesia dan mendapatkan surat keterangan lolos kaji etik sehingga penelitian dapat dilakukan.

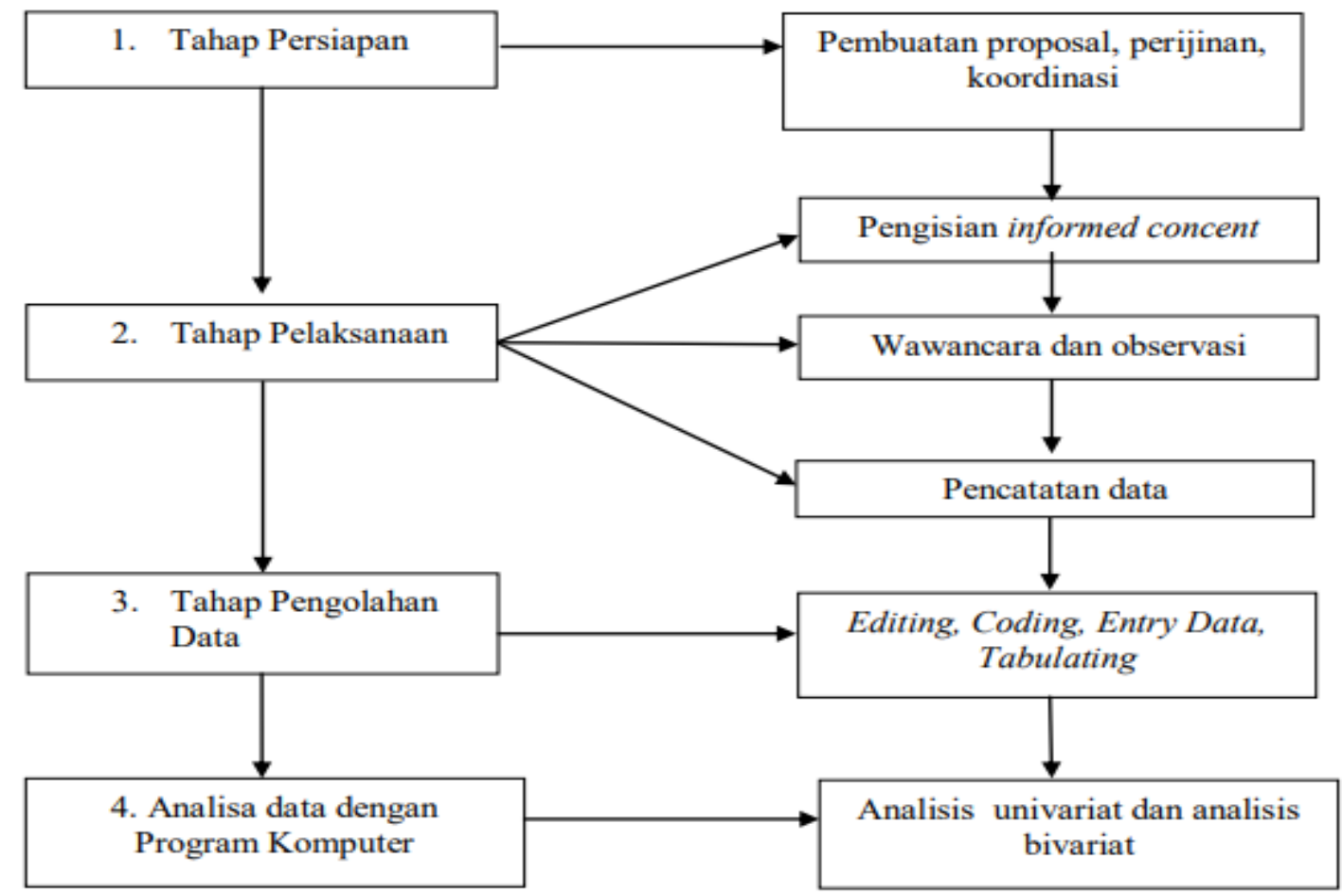

Gambar 1. Diagram Alur Penelitian

\section{Hasil Penelitian}


Prosedur pengumpulan data penelitian ini dilakukan dalam beberapa tahap yaitu: (1). Meminta surat pengantar untuk melakukan penelitian setelah proposal disetujui oleh pembimbing (pembuatan proposal, perijinan, koordinasi) pada 02 Maret 2020, kemudian dilanjutkan dengan pengajuan etik untuk penelitian dan dinyatakan layak etik berdasarkan surat No. 011/SK.KEPK/UNR/III/2020, tertanggal 19 Maret 2020. (2). Tahap persiapan wawancara dan observasi, dengan melakukan koordinasi dengan pihak Puskesmas Kecamatan, Kepala Kelurahan Bambu Apus dan Cipayung serta Wilayah RW dan Kader, pada bulan Maret 2020 dan sempat terkendala karena kondisi Pandemi Covid 19 dan PSBB di Wilayah Jakarta. (3). Tahap pelaksanaan: mengajukan surat permohonan izin (sesuai prosedur permohonan ijin mulai dari PTSP Propinsi DKI Jakarta, Dinkes Propinsi DKI dilanjutkan Ke Sudin Jakarta Timur dan Puskesmas Kecamatan Cipayung, dengan proses yang lama mulai April-September 2020). Sebelum dan sesudah ke lapangan semua tim enumerator melakukan rapid tes dan selama pengambilan data mematuhi protokol kesehatan secara ketat, kemudian mengajukan surat permohonan izin kepada calon responden yang bersedia berpartisipasi dalam penelitian, menjelaskan tentang manfaat penelitian, tujuan penelitian, dan kerahasiaan informasi yang akan diperoleh dari responden, pengisian informed concern. Pengambilan data dilakukan pada tanggal 01-07 Oktober 2020. Didapatkan responden sejumlah 67 Balita. (4) Editing, coding, entry data, tabulating, ${ }^{1)}$ dilaksanakan pada tanggal 07-10 Oktober 2020 (5). Tahap pengolahan data dan pencatatan data, dilaksanakan paralel pada tanggal 07-10 Oktober 2020. (6). Analisa data dengan program komputer (analisis univariat untuk mendeskripsikan karakteristik responden, variabel dependen status gizi balita dan variabel independen pola asuh keluarga dan pemberian MP-ASI. Data dikumpulkan dan kemudian disajikan dalam bentuk tabel dan dipersentasikan serta di analisis dalam bentuk narasi, selanjutnya di analisis dan. Data disajikan dan di interpretasikan. Analisis Bivariat dilakukan untuk mengetahui hubungan antara variabel dependen status gizi balita dengan variabel independent pola asuh keluarga dan pemberian MP-ASI, dengan menggunakan uji statistik Chi-Square) dilanjutkan dengan pembahasan pada tanggal 10-15 Oktober 2020. Kemudian diseminasi hasil penelitian dilaksanakan 
pada tanggal 17 November 2020 dalam rangkaian kegiatan Webinar yang dilaksanakan oleh Lembaga Penelitian dan Pengabdian Masyarakat secara daring. Selain itu juga dihasilkan manuskrip di Hasil Analisis dan Pembahasan.

1) Analisis Univariat

a. Status Gizi Balita jurnal terakreditasi dan sertifikat $\mathrm{HaKI}$ dalam bentuk Buku Saku Pendamping Hasil Penelitian : Status Gizi Balita dan FaktorFaktor yang mempengaruhinya.

Tabel 1

Distribusi Frekuensi Responden Berdasarkan Status Gizi Balita Di Kelurahan Cipayung

\begin{tabular}{lcc}
\hline \multicolumn{1}{c}{ Status Gizi Balita } & Frekuensi & Persentase (\%) \\
\hline Normal & 47 & 70.1 \\
Tidak Normal & 20 & 29.9 \\
\hline Bumlah & $\mathbf{6 7}$ & $\mathbf{1 0 0}$ \\
\hline
\end{tabular}

menunj

erdasarkan tabel 1, dapat diketahui dari 67 responden terdapat 47 (70.1\%) balita yang gizi normal dan 20 (29.9\%) balita yang gizi tidak normal. Menurut Suparisa,dkk, 2017 Status gizi adalah keadaan tubuh sebagai akibat dari pemakian, penyerapan dan penggunaan makanan. Status gizi balita mencerminkan tingkat perkembangan dan kesejahteraan masyarakat dalam suatu negara serta berhubungan dengan status gizi anak dimasa depan (Supariasa, 2017).

Penelitian ini mendapatkan hasil yang sama dengan penelitian Yourisna Pasambo di Kecamatan Tamalate Kota Makassar Tahun 2014. Hasil penelitian ukkan bahwa balita yang memiliki status gizi baik sebanyak 10 orang $(45,5 \%)$, yang memiliki status gizi kurang sebanyak 11 orang $(50,0 \%)$, sementara balita dengan status gizi buruk sebanyak 1 orang $(4,5 \%)$. Hasil ini menunjukkan bahwa balita dengan status gizi kurang lebih banyak dari pada balita dengan status gizi baik. Salah satu hal yang menjadi penyebabnya adalah kurangnya intake nutrisi yang seimbang pada balita tersebut. Kondisi ini dapat didukung dengan kurangnya pengetahuan ibu tentang gizi seimbang. Demikian juga penelitian yang dilakukan oleh Rosna, 2017. 
Menurut peneliti status gizi balita di Kelurahan Cipayung Jakarta Timur banyak yang normal dibandingkan tidak normal. Hal ini disebabkan lebih banyak balita yang lahir dengan berat badan normal, imunisasi b. Pola Asuh Keluarga lengkap dan rutin melakukan aktifitas pelayanan kesehatan seperti penimbangan berat badan dan pengukuran tinggi badan untuk mengetahui status gizi balita menurut umur.

Tabel 2

Distribusi Frekuensi Responden Berdasarkan Pola Asuh Keluarga di Kelurahan Cipayung

\begin{tabular}{lll}
\hline Pola Asuh & Frekuensi & Persentase (\%) \\
\hline Baik & 29 & 43.3 \\
Tidak Baik & 38 & 56.7 \\
\hline Jumlah & $\mathbf{6 7}$ & $\mathbf{1 0 0}$ \\
\hline
\end{tabular}

Berdasarkan tabel 2, diketahui dari 67 responden terdapat 29 (43.3\%) pola asuh baik dan terdapat $36(28.4 \%)$ pola asuh tidak baik. Menurut Septriani, 2018 Pola asuh merupakan suatu sikap, membimbing, mendidik dan interaksi orang tua kepada anak untuk mendorong pertumbuhan dan perkembangan anak dengan harapan anak dapat sukses menjalani kehidupan (Septriani, 2018).

\section{c. Pemberian MP-ASI}

Tabel 3

Distribusi Frekuensi Responden Berdasarkan Pemberian MP-ASI

di Kelurahan Cipayung

\begin{tabular}{lll}
\hline Pemberian MP-ASI & Frekuensi & Persentase (\%) \\
\hline Cukup & 32 & 47.8 \\
Kurang & 35 & 52.2 \\
\hline Jumlah & $\mathbf{6 7}$ & $\mathbf{1 0 0}$
\end{tabular}

B

responde

erdasarkan tabel 3, diketahui dari 67

$\mathrm{n}$ terdapat $32(47.8 \%)$ pemberian MP 
ASI cukup dan terdapat 35 (52.2\%)

pemberian MP ASI kurang. Menurut Krisnatuti, $2017 \quad$ Makanan pendamping ASI (MP-ASI) adalah makanan tambahan yang diberikan kepada bayi setelah bayi berusia 6 bulan sampai bayi berusia 24 bulan. Jadi selain Makanan Pendamping ASI, ASI-pun harus tetap diberikan kepada bayi, paling tidak sampai usia 24 bulan, peranan makanan pendamping

\section{2) Analisis Bivariat}

\section{a. Hubungan Pola Asuh Dengan Status Gizi Balita}

Tabel 4
ASI sama sekali bukan untuk menggantikan ASI melainkan hanya untuk melengkapi ASI jadi dalam hal ini makanan pendamping ASI berbeda dengan makanan sapihan diberikan ketika bayi tidak lagi mengkonsumsi ASI (Septriani, B. 2018; Diah Krisnatuti dan Rina Yenrina. 2017; Umbu Zogara. 2020)

Hubungan Pola Asuh Dengan Status Gizi Balita

Di Kelurahan Cipayung Jakarta Timur

\begin{tabular}{|c|c|c|c|c|c|c|c|}
\hline \multirow[t]{3}{*}{ Pola Asuh } & \multicolumn{4}{|c|}{ Status Gizi Balita } & \multirow[t]{2}{*}{ Total } & \multirow{3}{*}{$\rho$-value } & \multirow{3}{*}{$\begin{array}{c}\text { OR } \\
(95 \%)\end{array}$} \\
\hline & \multicolumn{2}{|c|}{ Normal } & \multicolumn{2}{|c|}{ Tidak Normal } & & & \\
\hline & $\mathbf{N}$ & (\%) & $\mathbf{N}$ & (\%) & n (\%) & & \\
\hline Baik & 26 & 89,7 & 3 & 10,3 & $29(100)$ & 0,005 & 7,016 \\
\hline Tidak Baik & 21 & 55,3 & 17 & 44,7 & $38(100)$ & & $(1,809-27,210)$ \\
\hline
\end{tabular}

Berdasarkan tabel 4, bahwa balita yang pola asuh baik ada $89,7 \%$. Sedangkan balita yang pola asuh tidak baik ada 55,3 \%. Hasil uji chi-square nilai $p \quad 0,005$ artinya $p<$ 0,05 sehingga dapat disimpulkan secara stastistik ada hubungan yang signifikan antara pola asuh dengan status gizi balita. Diperoleh nilai OR 7,016 yang artinya balita yang pola asuh tidak baik mempunyai resiko 7,016 kali lebih besar di bandingkan balita yang pola asuh baik.

Penelitian ini sejalan dengan penelitian di Posyandu Menur Kelurahan Bujel Kota Kediri Tahun 2019. Didapatkan tingkat signifikasi 0,001 dimana nilai $\rho<\alpha$ 0,05 maka dapat disimpulkan ada 
hubungan antara pola asuh dengan status gizi pada balita di Pemberian makan yang baik sangat penting untuk asupan nutrisi, tidak hanya dari segi apa yang dimakan anak, tapi sikap ibu juga berperan.

Asumsi peneliti mengenai penelitian pola asuh keluarga berpengaruh terhadap gizi balita karena pola asuh keluarga tidak baik seperti nenek, kakek, saudara dan IRT tidak memperhatikan waktu makan dan makanan bergizi seimbang untuk balita. Semakin baik pola asuh kelurga seperti nenek, kakek, saudara dan IRT semakin baikl status gizi balita (Aldriana. 2020; Sukandar. 2020)

\section{b. Hubungan Pemberian MP-ASI Dengan Status Gizi Balita}

Tabel 5

\section{Hubungan Pemberian MP-ASI Dengan Status Gizi Balita Di Kelurahan Cipayung Jakarta Timur}

\begin{tabular}{|c|c|c|c|c|c|c|c|}
\hline \multirow{3}{*}{$\begin{array}{c}\text { Pemberian } \\
\text { MP-ASI }\end{array}$} & \multicolumn{4}{|c|}{ Status Gizi Balita } & \multirow[t]{2}{*}{ Total } & \multirow{3}{*}{$\rho$-value } & \multirow{3}{*}{$\begin{array}{c}\text { OR } \\
\text { (95\%) }\end{array}$} \\
\hline & \multicolumn{2}{|c|}{ Normal } & \multicolumn{2}{|c|}{ Tidak Normal } & & & \\
\hline & $\mathrm{N}$ & (\%) & $\mathrm{N}$ & $(\%)$ & n (\%) & & \\
\hline Cukup & 27 & 84,4 & 5 & 15,6 & $32(100)$ & 0,030 & 4,050 \\
\hline Kurang & 20 & 57,1 & 15 & 42,9 & $(100)$ & & $(1,262-12,992)$ \\
\hline
\end{tabular}

Berdasarkan tabel \%, bahwa balita yang pemberian MP ASI cukup ada 84,4 \%. Sedangkan balita yang pemberian MP ASI kurang ada 57,1\%. Hasil uji chi-square nilai p 0,030 artinya $p<0,05$ sehingga dapat disimpulkan secara stastistik ada hubungan yang signifikan antara pemberian mp-asi dengan status gizi balita. Diperoleh nilai 4,050 yang artinya balita yang pemberian mp-asi kurang mempunyai resiko 4,050 kali lebih besar di bandingkan pemberian MPASI cukup.
Penelitian ini sejalan dengan Datesfordate di wilayah kerja Puskesmas Bahu Manado, menunjukan hasil bahwa dari 79 responden, yang memiliki MP-ASI Baik dengan status gizi baik sebanyak 34 responden (43.0\%), MP-ASI baik dengan Status gizi buruk sebanyak 23 responden (29.0\%), MP-ASI buruk dengan status gizi buruk sebanyak 20 responden (25.3\%), MPASI buruk dengan status gizi baik sebanyak 2 responden (2.5\%). Berdasarkan hasil uji statistik chi square di peroleh nilai 
$p=0.000$ hal ini berarti dikatakan Hipotesis H1 diterima dan $\mathrm{HO}$ di tolak. Hal ini menyatakan bahwa terdapat hubungan

Asumsi peneliti mengenai penelitian pemberian MP-ASI berpengaruh terhadap gizi balita karena jumlah dan jenis makanan yang di berikan kepada balita harus sesuai dengan umur dan kebutuhan makanan balita sehari - hari selain itu pendidikan ibu berpengaruh terhadap pemberian MP-ASI dalam pemilihan menu makanan yang di konsumi setiap hari berbeda tetapi kebutuhan gizi seimbang tercukupi (Silvia, 2020).

\section{Simpulan}

Balita di Kelurahan Cipayung Jakarta Timur ada 67 orang terdapat 47 (70.1\%) balita gizi normal dan terdapat 20 (29.9\%) balita gizi tidak normal. Variabel pola asuh dan pemberian MP-ASI berhubungan signifikan dengan status gizi balita.

Hasil penelitian ini diharapkan dapat memberikan informasi mengenai status gizi balita dan dapat menurunkan angka kejadian gizi balita di wilayah kerja Puskesmas Cipayung Jakarta Timur, khususnya di Kelurahan Cipayung. Upaya yang dilakukan dengan pemenuhan nutrisi serta melakukan penyuluhan kesehatan tentang pemberian makanan dengan menu yang signifikan antara pemberian MP-ASI dengan status gizi bayi pada usia 6- 12 bulan.

gizi seimbang, memperhatikan waktu makan, porsi makan sesuai umur balita dan melakukan pemberian ASI Ekslusif selama 2 Tahun.

\section{DAFTAR PUSTAKA}

1. Alan Sukandar. 2020. Hubungan Pola Asuh dan Tingkat Pengetahuan Ibu tentang Pedoman Umum Gizi Seimbang dengan Status Gizi Balita di Desa Gumpang Kec. Kartasura. Jurnal KESMAS Vol 6 No 3.2020.Diunduh dari : http://ejournalhealth.com.

2. Asriani, 2012. Hubungan antara pola asuh, pengetahuan dan sikap orangtua, terhadap status iscepigizi balita. Jurnal Gizi Klinik Indonesia.

3. Bisma Murti, 2003. Prinsip Dan Metode Riset Epidemiologi. Yogyakarta: Gajah Mada iscep:University

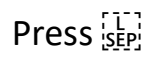

4. Depkes RI. 2013. Riset Kesehatan Dasar 2013. Badan Penelitian dan Pengembangan Kementerian Kesehatan Republik Indonesia șẹp:

5. Depkes, RI., 2008. Pedoman Umum Gizi Seimbang. Jakarta: Ditjen 
Pembinaan Kesehatan iscepiMasyarakat.

Direktorat Bina Gizi Masyarakat. Jakarta išpe:

6. Diah Krisnatuti dan Rina Yenrina. 2017. Menyiapkan Makanan Pendamping ASI. Jakarta: Puspa Swara.

7. Hastono, Sutanto Priyo. 2016. Analisis Data Bidang Kesehatan. Jakarta : Raja Grafindo Persada.

8. Helmi Rumbo, Astin. Hubungan Pemberian Asi Ekslusif Dengan Status Gizi Balita. Vol. 1, No. 01, Januari 2019 ISSN online: XXXX-XXX. file:///C:/Users/Windows7/Download s/29-Article\%20Text-74-1-1020200120.pdf. Diakses 23 Agustus 2020.

9. Hidayat,A.AzizAlimul.2007.MetodePen elitianKeperawatandanTeknikAnalisaD ata. Jakarta : Salemba Medika.

10. http://www.wpro.who.ints

Sulistidjani, 2004. Menjaga kesehatan bayi dan balita. Jakarta : Puspa

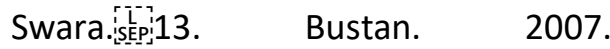
Epidemiologi Penyakit Tidak Menular. Jakarta: Rineka Ciptaišpepi14.Hardani Rika, 2002. Pola Makan Sehat. Makalah Seminar Online Kharismake 2

11. Nana Aldriana. 2020. Faktor-Faktor Yang Mempengaruhi Status Gizi Balita
Di Desa Kepenuhan Hulu Wilayah Kerja Puskesmas Kepenuhan Hulu. Journal Endurance Vol 2 NO 2. 2017.http://ejournal.kopertis10.or.id. Diakses 23 Agustus 2020.

12. Notoatmodjo, S. 2010. Metodologi Penelitian Kesehatan. Jakarta: Rineka

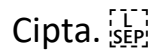

13. Profil Kesehatan Puskesmas Kecamatan Cipayung, Tahun 2018

14. Putri Rona F, Sulastri Deni, dan Lestari Yuniar. Faktor Faktor Yang Berhubungan dengan Status Gizi Anak Balita di Wilayah Kerja Puskesmas Nanggalo Padang. Jurnal Kesehatan Andala Vol 4 No 1. 2018. Diunduh dari:

http://jurnal.fk.unand.ac.id/index.php / jka/article/view/231 . Diakses 23 Maret 2020.

15. Rahmawati, 2014. Tips dan Resep Sehat MP ASI. Yogyakarta : Trans Idea Publishing. [iche

16. Reni Meliasari, 2013. Hubungan pola asuh makan oleh ibu bukan pekerja dengan status išepi:gizi baduta istepi

17. Riset Kesehatan Dasar.2007. Kementrian Kesehatan Republik Indonesia; Badan istepenelitian dan Pengembangan Kesehatan. Jakarta ișpis 
18. Riskesdas, 2013. Pusat Teknologi Kesehatan Masyarakat Badan Penelitian dan Kesehatan Kemenkes RI 2014 is sêp:

19. Septriani, B. 2018. Mencetak Balita Cerdas dan Pola Asuh Orang Tua. Yogyakarta : Nuha Medika.

20. Silvia Ari Agustina, Melisa Putri Rahmadhena. Analisis Determinant Masalah Gizi Balita. Jurnal KesehatanVolume11 nomor 01 (2020) 008 014.2019 .

http://ejurnal.stikesprimanusantara.a c.id/. Diakses 6 Agustus 2020

21. Sunita Almatsier, 2006. Penuntun Diet. Jakarta: Gramedia Pustaka Utama issep?
22. Supariasa 2002, Penentuan Status Gizi, Jakarta isẸ:

23. Suparisa, I.D.N. Bachyar Bakri dan Ibnu Fajar. Penilaian Status Gizi Balita. Jakarta : EGH ; 2017.

24. Umbu Zogara. 2020. Pemberian Makanan Pendamping ASI (MPASI) dan Status Gizi Balita di Kelurahan Tuak Daun Merah. Chmk health journal. Volume 4 nomor 1, januari 2020.diakses 6 agustus 2020.

25. World Health Organization (WHO). 2012. of Diseases in 2002. WHO Global Infobase. 